\title{
Inventory of pollutant emission from motor vehicles in Poland using the COPERT 5 software
}

This article presents results of the inventory of pollutant emission from motor vehicles in Poland. To determine emission from motor vehicles in Poland COPERT 5 software was used for the first time. In addition, a comparison of the national emission from motor vehicles in 2016 and in 2015 was included. Pollutants harmful to health were considered primarily: carbon monoxide, organic compounds, nitrogen oxides and particulate matter. Emission of substances contributing to the intensification of the greenhouse effect were also examined: carbon dioxide, ammonia and nitrous oxide. It was found that the relative increase in volume of emission of carbon monoxide and non-methane volatile organic compounds is less than 10\%, and nitrogen oxides and particulate matter less than $15 \%$. The relative increase in carbon dioxide emission is approximately 14\%, which corresponds to a relative increase in fuel consumption. The relative increase of volume of heavy metal emission is similar. The assessment of the energy emission factor (emission of pollution related to energy equal to used fuel) proves that - amongst pollutants harmful to health - for carbon monoxide and non-methane volatile organic compounds there is a relative reduction by approximately 5\% in 2016, and for nitrogen oxides and particulate matter - increase by approximately $(3-4) \%$.

Key words: inventory of pollutant emission, motor vehicles

\section{Introduction}

Since 2017, a new version of the software - COPERT 5 has been used for the purpose of the inventory of pollutant emission from motor vehicles $[4,5]$. The new version differs from the previous one, among others in the structure of motor vehicles - this is primarily due to the differences offered by manufacturers of types of vehicles. There are also some differences in the emission characteristics of individual substances, that are mainly the result of increasing level of knowledge of the ecological properties of motor vehicles considering emission of pollutants under conditions simulating real operation.

Therefore, it is advisable to conduct an inventory of pollutants from motor vehicles using the new version of the software. Such inventory was performed for Poland for the year 2016 as part of pollutant emission reporting. For comparative purposes also pollutant emission from motor vehicles for previous years was inventoried.

Detailed methodology for the selection of COPERT software input data has been described in publications [1-3] - there are no significant differences compared to the COPERT 4 software version [4].

The main differences in the software input data for 2016 in relation to 2015 year result from variations in the number of vehicles in each category and the consumption of different types of fuels.

Figure 1 shows the number of motor vehicles in Poland in 2016 and in 2015 for cumulative vehicle categories:

- passenger cars with gasoline spark ignition engine - PC-G,

- passenger cars with compression ignition engine - PC-D,

- passenger cars with liquefied petroleum gas spark ignition engine PC-LPG,

- light duty vehicles with spark ignition engine - LDV-G,

- light duty vehicles with compression ignition engine LDV-D,
- heavy duty vehicles - HDV,

- buses with compression ignition engine - B-D,

- NG (natural gas): CNG (compressed natural gas) and LNG (liquefied natural gas) buses $-\mathrm{B}-\mathrm{CNG}^{1}$,

- motorcycles and mopeds - M.

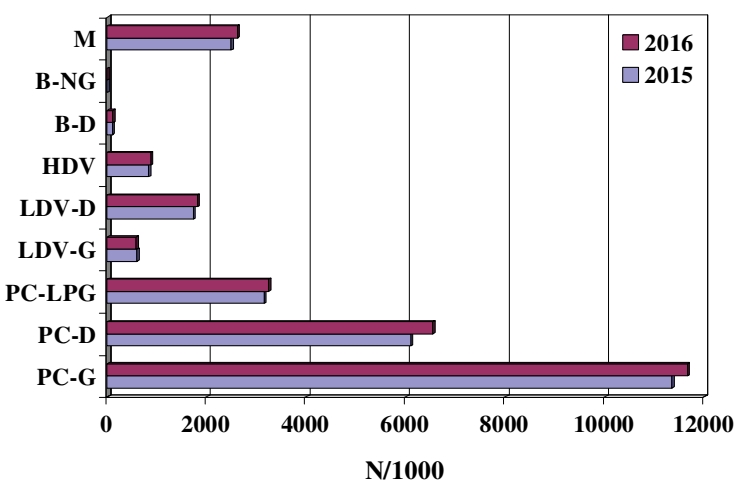

Fig. 1. The number of motor vehicles in Poland in years 2015 and 2016

Differences in the number of vehicles in cumulative categories should be assessed as minor - Fig. 2.

The relative difference in most cases does not exceed $7 \%$. Only in the case of buses equipped with engines powered by natural gas the number of vehicles is noted to increase. In the relative difference reaches $12 \%$. It is also noted the decrease in the number of light duty vehicles with spark ignition engine, which is understandable tendency for economic reasons.

\footnotetext{
${ }^{1}$ The COPERT software officially encompasses categories of vehicles equipped with CNG-powered natural gas (CNG) engines. In fact, also liquefied natural gas (LNG) is applied. For this reason, a reference NG (natural gas) is used both for natural gas and compressed and liquefied gas.
} 


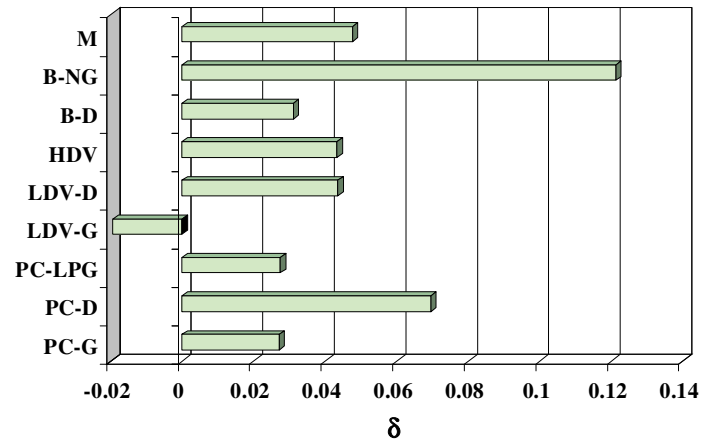

Fig. 2. The relative difference of motor vehicles number in Poland in 2016 year versus 2015 year

Figure 3 shows the consumption of fuels: gasoline $-\mathrm{G}$, diesel - D, liquefied petroleum gas - LPG and natural gas - NG.

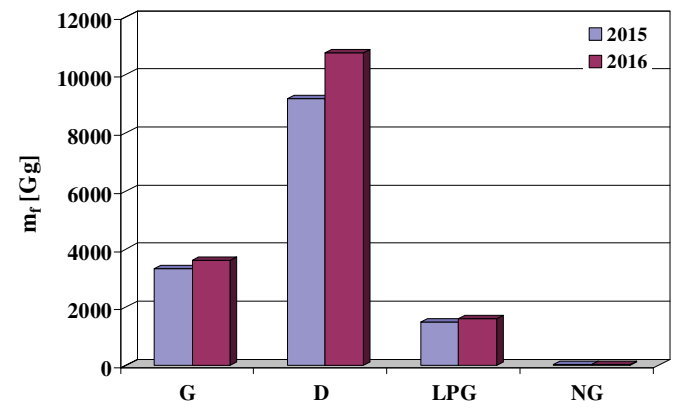

Fig. 3. Fuel consumption from motor vehicles in years 2015 and 2016

There is a significant increase in the consumption of diesel fuel in 2016 comparing to 2015 - a relative difference in consumption of diesel is more than $15 \%$.

The correlation between consumption of different types of fuel, determined as a result of the emission inventory and reported fuel consumption confirms the validity of adopted data for the COPERT software.

\section{National annual emission of pollutants from motor vehicles in 2016 comparing to 2015}

Figures 4-14 present the national annual emission from motor vehicles in Poland in 2015 and in 2016 of the following substances [6]:

- carbon monoxide - $\mathrm{CO}$,

- non-methane volatile organic compounds - NMVOC,

- methane $-\mathrm{CH}_{4}$,

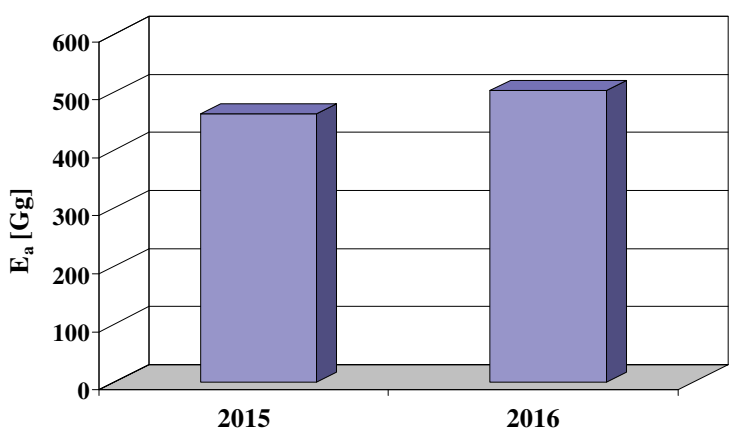

Fig. 4. National annual emission of carbon monoxide from motor vehicles in 2015 and 2016
- nitrogen oxides reduced to nitrogen dioxide $-\mathrm{NO}_{\mathrm{x}}$,

- total suspended particles - TSP,

- particulate matter PM10,

- particulate matter PM2.5,

- BC - black carbon,

- carbon dioxide $-\mathrm{CO}_{2}$,

- nitrous oxide $-\mathrm{N}_{2} \mathrm{O}$,

- ammonia $-\mathrm{NH}_{3}$.

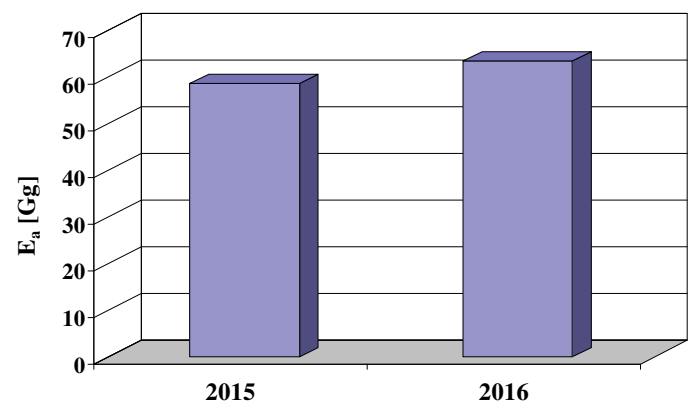

Fig. 5. National annual emission of non-methane volatile organic compounds from motor vehicles in 2015 and 2016

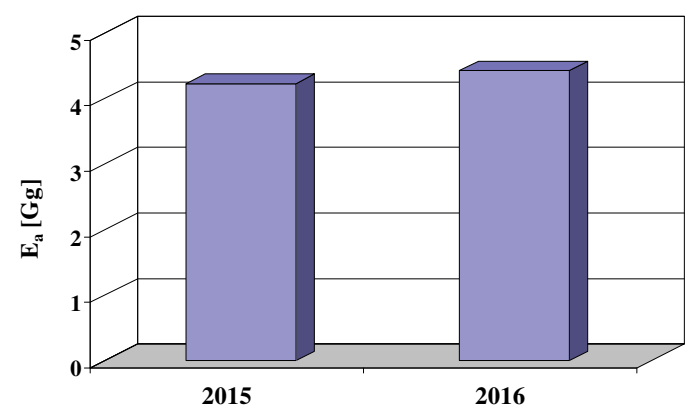

Fig. 6. National annual emission of methane from motor vehicles in 2015 and 2016

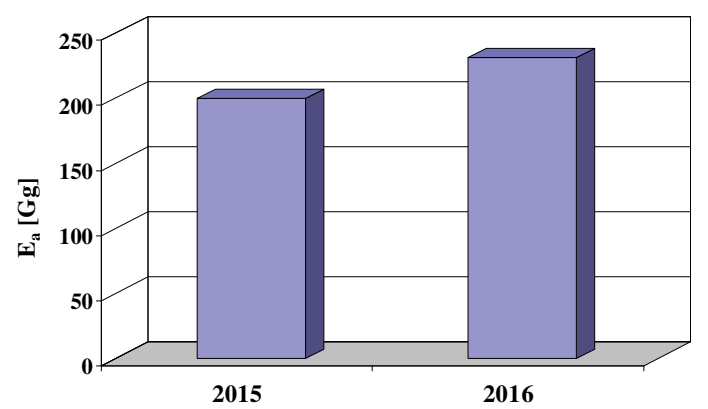

Fig. 7. National annual emission of nitrogen oxides from motor vehicles in 2015 and 2016

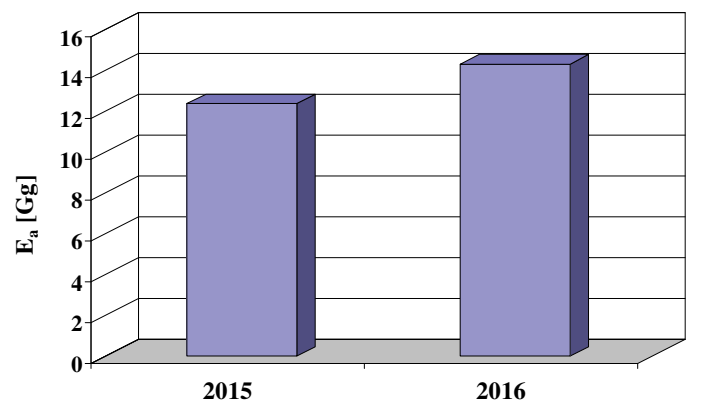

Fig. 8. National annual emission of total suspended particles from motor vehicles in 2015 and 2016 


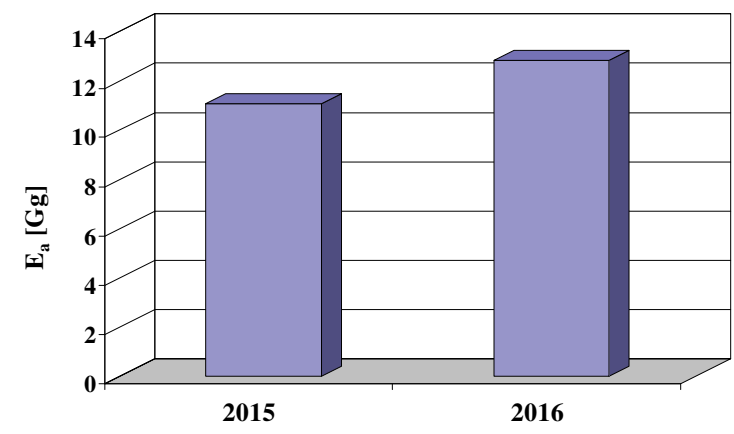

Fig. 9. National annual emission of particulate matter PM10 from motor vehicles in 2015 and 2016

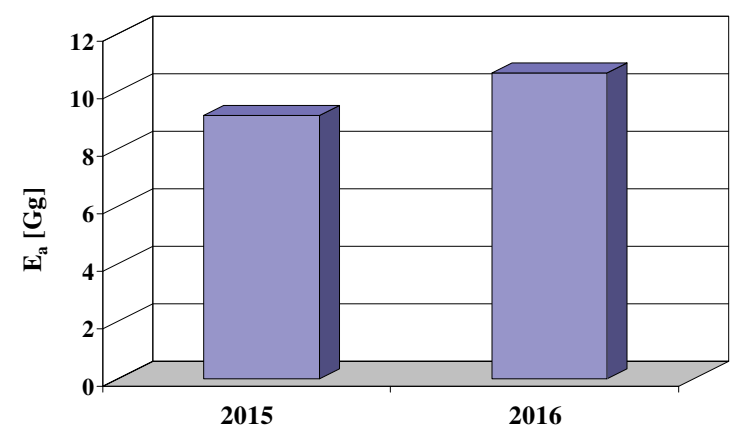

Fig. 10. National annual emission of particulate matter PM2.5 from motor vehicles in 2015 and 2016

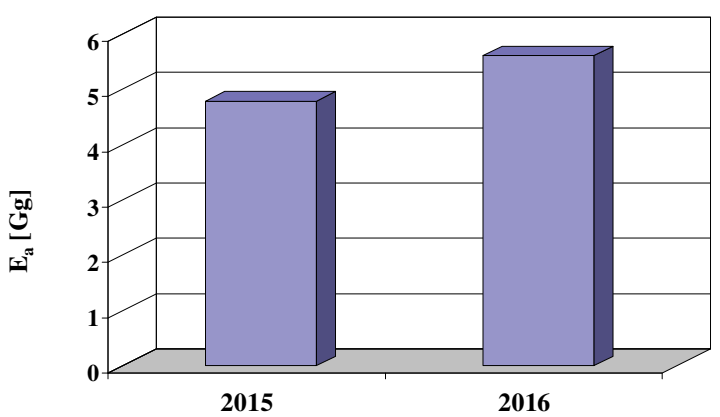

Fig. 11. National annual emission of black carbon from motor vehicles in 2015 and 2016

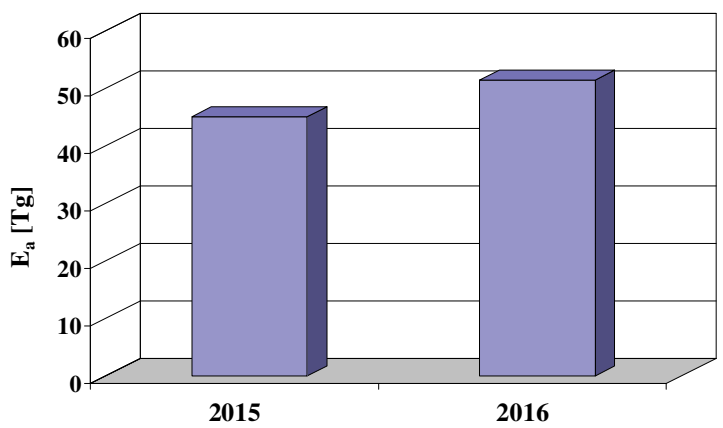

Fig. 12. National annual emission of carbon dioxide from motor vehicles in 2015 and 2016

Differences in values of the national annual emission of pollutants from motor vehicles comparing years 2015 and 2016 are small. In all cases there was an increase in the national annual emission of pollutants, which results mainly from the increase in the number of vehicles in individual cumulated categories (with the exception of light commercial trucks with spark ignition engines) and - as a consequence - from an increase in fuel consumption. The increase of the national annual emission in 2016 as compared to 2015 is various for particular pollutants. Therefore, it was decided to compare the relative change in the national annual emission of all inventoried substances between 2016 and 2015 in relation to the national average annual emission of pollutants for those years. This analysis also includes the results of heavy metal emission - emission is primarily determined by the use of different fuels.

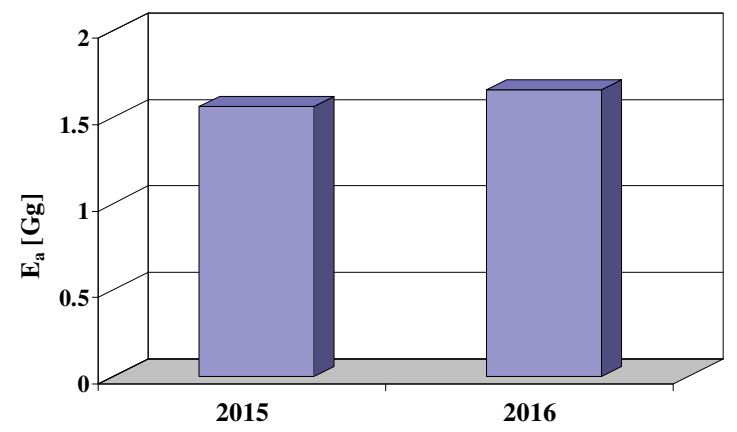

Fig. 13. National annual emission of nitric dioxide from motor vehicles in 2015 and 2016

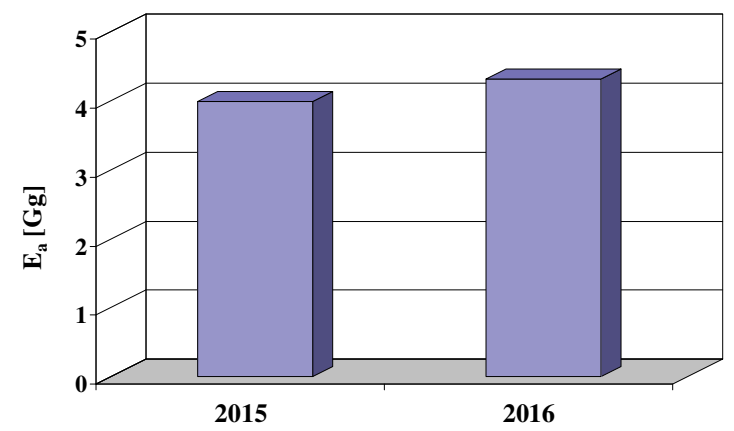

Fig. 14. National annual emission of ammonia from motor vehicles in 2015 and 2016

Figures 15-17 show the relative difference in annual emission of pollutants comparing 2016 to 2015 . The relative difference is defined as:

$$
\delta=2 \cdot \frac{\mathrm{x}_{2016}-\mathrm{x}_{2015}}{\mathrm{x}_{2016}+\mathrm{x}_{2015}}
$$

where: $\mathrm{x}_{2015}, \mathrm{x}_{2016}$ - the value in 2015 and 2015 .

The relative difference in annual emission of pollutants comparing 2016 to 2015 is small - it does not exceed $15 \%$. The largest relative difference in national annual emission is noted for particulates, especially for their carbon part. The increase in the annual national emission of carbon dioxide is associated with higher consumption of fossil fuels in 2016, due to a larger number of vehicles. The smallest relative difference in national annual emission is noted for volatile organic compounds, primarily methane, and for nitrous oxide. 


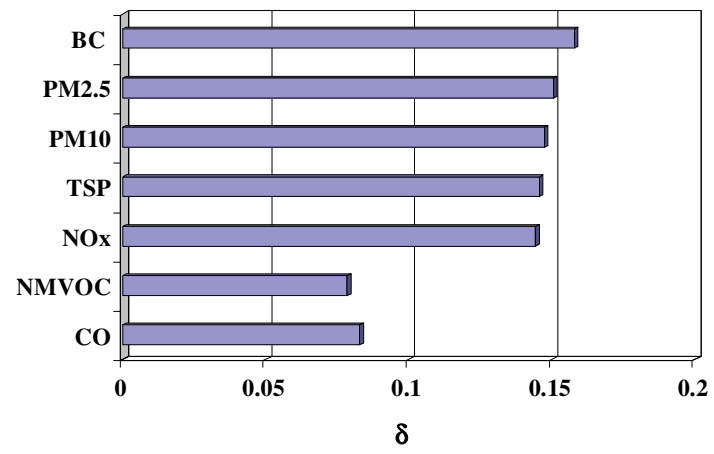

Fig. 15. The relative difference of national annual pollutant emission from motor vehicles in Poland comparing 2015 to 2016

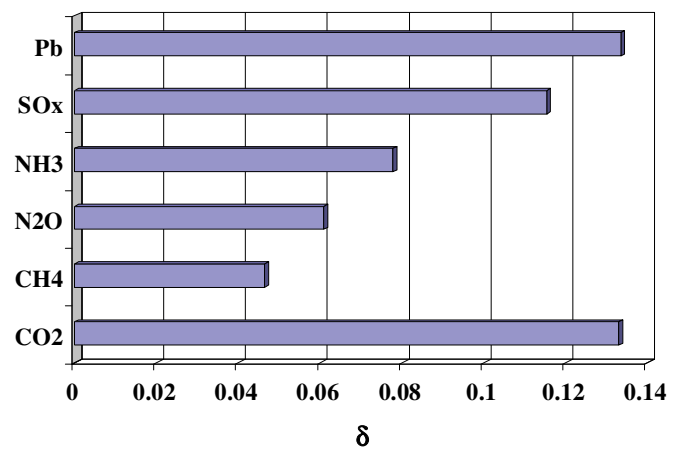

Fig. 16. The relative difference of national annual pollutant emission from motor vehicles in Poland comparing 2016 to 2015

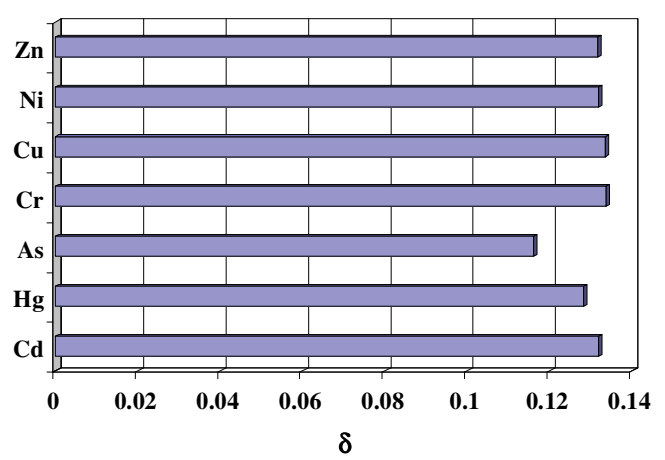

Fig. 17. The relative difference of national annual pollutant emission from motor vehicles in Poland comparing 2016 to 2015

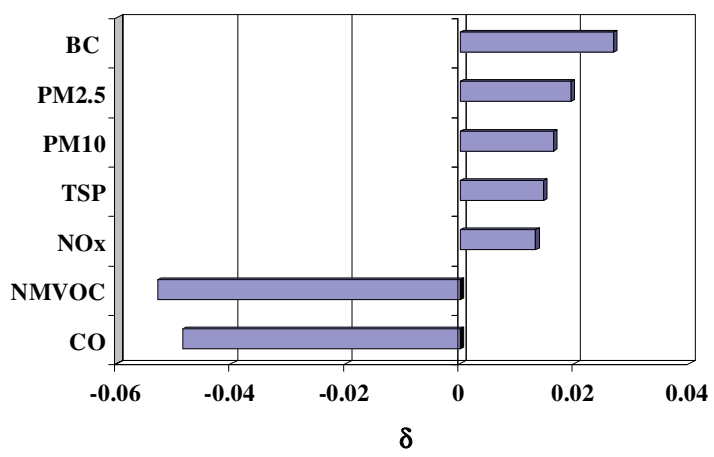

Fig. 18. The relative difference of average energetic index of pollutant emission from motor vehicles in Poland comparing 2015 to 2016

In order to compare the ecological properties of vehicles with regard to the emission of pollutants in 2015 and 2016, the average energy emission factor of these substances was determined for individual substances.

$$
\mathrm{WE}=\frac{\mathrm{E}_{\mathrm{a}}}{\mathrm{R}_{\mathrm{a}}}
$$

where: $R_{a}$ - energy equal to the annual consumption of fuels, determined in accordance with their calorific value.

Figures 18-20 show the relative difference in the average energy pollution emission factor from motor vehicles in Poland comparing 2016 to 2015.

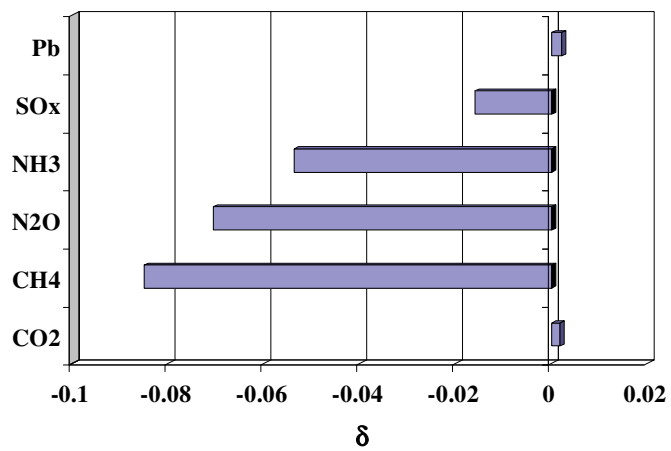

Fig. 19. The relative difference of average energetic index of pollutant emission from motor vehicles in Poland comparing 2015 to 2016

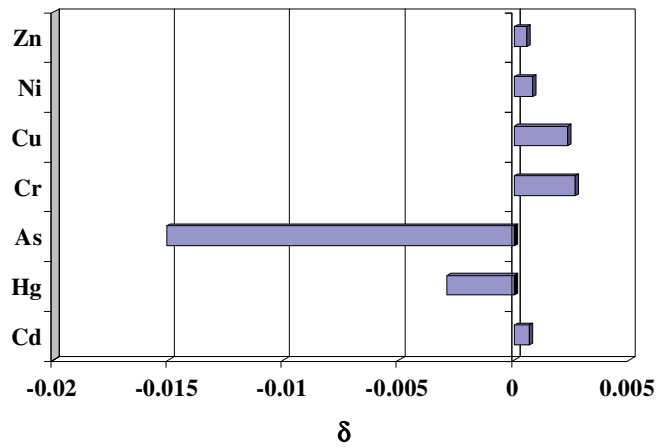

Fig. 20. The relative difference of average energetic index of pollutant emission from motor vehicles in Poland comparing 2015 to 2016

\section{Recapitulation}

In the summary following conclusions may be drawn from presented research results:

1. Presented results of the total emission of pollutants from motor vehicles are the result of the first use in Poland of COPERT 5 software to official reporting of emission in the framework of cooperation within the European Union.

2. Among the cumulated categories of large-capacity vehicles, the number of passenger cars with compression engines is the category number of which increased the most in 2016.

3. Among fuels consumed by automotive vehicles in 2016, diesel oil consumption increased the most.

4. In 2016, the relative increase in volumes of emission of carbon monoxide and non-methane volatile organic compounds is less than $10 \%$, and nitrogen oxides and particulate matter less than $15 \%$.

5. In 2016, the relative increase in volume of carbon dioxide emission is around $14 \%$, which corresponds to a relative increase in fuel consumption. The relative increase in volume of heavy metal emission is similar.

6. Results of testing the energy emission factor proves that - among contaminants posing a threat to human health - 
the energy emission factor for carbon monoxide and non-methane volatile organic compounds shows in 2016 a relative reduction ratio by approximately $5 \%$, and the factor for the nitrogen oxides and particulate matter increase by approximately (3-4)\%. For heavy metals, the relative change in the energy emission factor is small. A light increase also occurs in the case of carbon dioxide, which results from the fact that in subsequent years larger car vehicles are used more often. This is due to the commercial aspects of placing vehicles in the market - contrary to popular publicity concerning the use of smaller cars. This fact is noticeable in both lightduty and heavy-duty vehicles.

\section{Nomenclature}

\begin{tabular}{|c|c|c|c|}
\hline As & arsenic & $\mathrm{NH}_{3}$ & ammonia \\
\hline $\mathrm{BC}$ & black carbon & $\mathrm{Ni}$ & nickel \\
\hline B-D & buses with compression ignition engine & NMVOC & non-methane volatile organic compounds \\
\hline $\mathrm{B}-\mathrm{NG}$ & NG buses & $\mathrm{NO}_{\mathrm{x}}$ & nitrogen oxides \\
\hline $\mathrm{C}$ & coaches & $\mathrm{Pb}$ & lead \\
\hline $\mathrm{Cd}$ & cadmium & PC-D & passenger cars with compression ignition \\
\hline $\mathrm{CH}_{4}$ & methane & & engine \\
\hline $\mathrm{CNG}$ & compressed natural gas & PC-G & passenger cars with gasoline spark ignition \\
\hline $\mathrm{CO}$ & carbon monoxide & & engine \\
\hline $\mathrm{CO}_{2}$ & carbon dioxide & PC-LPG & passenger cars with liquefied petroleum gas \\
\hline $\mathrm{Cr}$ & chromium & & spark ignition engine \\
\hline $\mathrm{E}_{\mathrm{a}}$ & annual emission & PM10 & particular matter PM10 \\
\hline HDV & heavy duty vehicles & PM2.5 & particular matter PM2.5 \\
\hline $\mathrm{Hg}$ & mercury & $\mathrm{SO}_{2}$ & sulphur oxides \\
\hline LNG & liquefied natural gas & TSP & total suspended particles \\
\hline M & motorcycles and mopeds & $\mathrm{Zn}$ & zinc \\
\hline $\mathrm{N}_{2} \mathrm{O}$ & nitrous oxide & $\delta$ & relative difference \\
\hline NG & natural gas & & \\
\hline
\end{tabular}

\section{Bibliography}

[1] BEBKIEWICZ, K., CHŁOPEK, Z., SZCZEPAŃSKI, K., ZIMAKOWSKA-LASKOWSKA, M. Assessment of results of pollutant emission inventory of the road transport sector in Poland in 2000-2015. The Archives of Automotive Engineering - Archiwum Motoryzacji. 2017, 78(4), 5-25.

[2] BEBKIEWICZ, K., CHŁOPEK, Z., SZCZEPAŃSKI, K., ZIMAKOWSKA-LASKOWSKA, M. Issues of modeling the total pollutant emission from vehicles. Proceedings of the Institute of Vehicles. 2017, 1(110), 103-118.

[3] BEBKIEWICZ, K., CHŁOPEK, Z., SZCZEPAŃSKI, K., ZIMAKOWSKA-LASKOWSKA, M. Results of air emission inventory from road transport in Poland in 2014. Proceedings of the Institute of Vehicles. 2017, 1(110), 77-88.

\footnotetext{
Katarzyna Bebkiewicz, MEng. - Institute of Environmental Protection - National Research Institute in Warsaw.

e-mail: katarzyna.bebkiewicz@kobize.pl
}

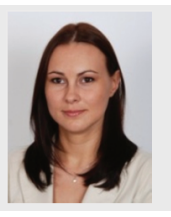

Prof. Zdzisław Chłopek, DSc., DEng. - Professor in the Institute of Environmental Protection - National Research Institute in Warsaw.

e-mail: zdzislaw.chlopek@kobize.pl

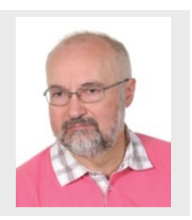

Magdalena Zimakowska-Laskowska, DSc., DEng. Institute of Environmental Protection - National Research Institute in Warsaw.

e-mail: magdalenazimakowska-laskowska@kobize.pl
[4] COPERT Training 5. COPERT 5 vs COPERT 4. European Environment Agency. 2016. http://emisia.com/sites/default/ files/COPERT_5_features.pdf. (2019-02-06).

[5] EMEP/EEA air pollutant emission inventory guidebook 2016. European Environment Agency.

[6] Poland's Informative Inventory Report 2018. Submission under the UN ECE Convention on Long-range Transboundary Air Pollution and the Directive (EU) 2016/2284 Warszawa, National Centre for Emission Management (KOBiZE) at the Institute of Environmental Protection - National Research Institute. February 2018.

Jakub Lasocki, DEng. - Faculty of Automotive and Construction Machinery Engineering, Warsaw University of Technology.

e-mail: jakub.lasocki@pw.edu.pl

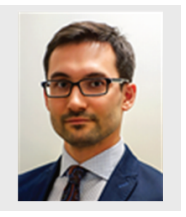

Krystian Szczepański, DSc., DEng. - Director of the Institute of Environmental Protection - National Research Institute in Warsaw.

e-mail: krystian.szczepanski@ios.edu.pl 